Annals of International Medical and Dental Research

E-ISSN: 2395-2822 | P-ISSN: 2395-2814

Vol-8, Issue-2 | March-April 2022

DOI: 10.53339/aimdr.2022.8.2.29

Page no- 233-237 | Section- Research Article (Haematology)

\title{
Insulino Mimetic Selenium in Type II Diabetes: Correlation with Blood Glucose
}

\section{Quamrun Nahar ${ }^{*}$, Nayeema Siddiqua ${ }^{2}$, Sheikh Khalid Saifullah Sadi ${ }^{3}$, Sheikh Nazrul Islam ${ }^{4}$}

1Principal Research Officer, Department of Clinical Pharmacology, Bangladesh Institute of Research and Rehabilitation in Diabetes, Endocrine and Metabolic Disorders (BIRDEM) Dhaka, Bangladesh. Email: quamrunnaharr@gmail.com,

Orcid ID: quamrunnaharr@gmail.com

2Department of Institute of Nutrition and Food Science, University of Dhaka, Dhaka, Bangladesh. Email: nayeema20@yahoo.com,

Orcid ID: 0000-0002-5074-2649

3Department of Institute of Nutrition and Food Science, University of Dhaka, Dhaka, Bangladesh. Email: dr.khalid.mmc@hotmail.com,

Orcid ID: https:/ /orcid.org/0000-0003-2934-2410

4Professor, Department of Institute of Nutrition and Food Science, University of Dhaka, Dhaka, Bangladesh. Email: Sheikhnazrul09@gmail.com, Orcid ID: 0000-0002-1969-9857

*Corresponding author

Received: 30 October 2021

Revised: 28 December 2021

Accepted: 19 January 2022

Published: 18 February 2022

\begin{abstract}
Background: Selenium has been reported to be insulinomimetic and to reduce blood glucose level in type 2 diabetes. Material \& Methods: This study describes an inverse correlation of serum selenium with blood glucose level. This is a case control study conducted among 30 low BMI and 70 normal BMI diabetes and 50 low BMI non-diabetic controls. Serum selenium concentration was determined by atomic absorption graphite spectrophotometry. Results: Serum selenium concentration was estimated to be $44 \pm 16 \mu \mathrm{g} / \mathrm{L}, 48 \pm 15 \mu \mathrm{g} / \mathrm{L}$ and $59 \pm 33 \mu \mathrm{g} / \mathrm{L}$ respectively in low BMI $(<18.5)$ and normal BMI (18.5-24.9) diabetics and low BMI nondiabetics controls. A trend of inverse correlation was found between serum selenium and blood glucose levels. Serum selenium level at $>$ $40(41-60) \mu \mathrm{g} / \mathrm{L}$ was found to be inversely correlated $(\mathrm{p}<0.05)$ with blood glucose level. Conclusions: Lower serum selenium was observed in the diabetic patients and it was inversely correlated with blood glucose level.
\end{abstract}

Keywords:- Insulino, Mimetic, Selenium, Blood Glucose.

\section{INTRODUCTION}

Selenium has been reported to be insulinomimetic, and it reduces blood glucose level in type 2 diabetes.[1,2,3]. Selenium stimulates glucose uptake, regulates metabolic process and directs specific $\beta$-cell target genes to promote islet function for the purpose of enhancing insulin synthesis and secretion. [1,] In contrast, high selenium load has been reported to be diabetogenic increasing the risk of type 2 diabetes and insulin resistance.[4] Some studies reported its inverse correlation with fasting blood glucose or prevalence of diabetes, someone obtained no correlation, [5] while others identified a positive association. [3,7] Meta-analysis reported a U-shaped non-linear dose-response relationship between selenium and diabetes. $[\underline{8}]$

Diabetes is a stress-induced metabolic disorder. The oxidative stress reduces insulin secretion, increases insulin resistance and develops glucose intolerance. $[9,10,11,12]$ Diabetes or hyperglycemia itself increases oxidative stress by generating excess reactive oxygen species.13] Oxidative insult of beta-cells has now been focused or addressed as the key aetiology of diabetes and insulin resistance.[14] Pancreatic beta-cells have low antioxidant 
Annals of International Medical and Dental Research

E-ISSN: 2395-2822 | P-ISSN: 2395-2814

Vol-8, Issue-2 | March-April 2022

DOI: 10.53339/aimdr.2022.8.2.29

Page no- 233-237 | Section- Research Article (Haematology)

capacity and are sensitive to oxidative stress. [14] Selenium is first line of antioxidant defense; in human its deficiency causes decreased glutathione peroxidases activity, and reduces insulin secretory reserve and makes glucose intolerance.[15] Selenium, through glutathione peroxidases (GPx), protects against oxidative stress, and thus, provides defense against diabetes. $[1,2,6,10,11,12]$ The present article reports an inverse correlation of serum selenium with type 2 diabetes.

\section{MATERIAL AND METHODS}

Selection and Description of Participants: The present study is a case control research conducted among 30 low BMI (<18.5) and 70 normal BMI (18.5-24.9) diabetes and 50 low BMI (<18.5) non-diabetic controls. The diabetic patients were recruited with defined criteria of BMI, blood glucose level and newly diagnosed, who were free from renal, heart and other complications. Technical Information. Estimation of blood glucose. A $3 \mathrm{ml}$ fasting blood sample was collected aseptically from anticubital vein of each of the diabetic and non-diabetic subjects and blood was processed to obtain serum. Serum glucose level was estimated by glucose-oxidase method using a glucose oxidase ELISA kit (Human, Germany). Serum selenium was analysed with atomic absorption graphite spectrometer (AA-680 Series, Shimadzu Corporation, Kyota, Japan).SPSS software package (Version 12.0, SPSS/PC Inc., Chicago, USA) was used to analyze the data. Descriptive statistics were used to calculate all variables. Values were expressed as mean, standard deviation and median. One way analysis of variance, independent t-test, and correlation analysis were performed.

\section{RESULTS}

Serum selenium was estimated to be $44 \pm 16 \mu \mathrm{g} / \mathrm{L}, \quad 48 \pm 15 \mu \mathrm{g} / \mathrm{L} \quad$ and $59 \pm 33 \mu \mathrm{g} / \mathrm{L}$ respectively in low BMI diabetics, normal BMI diabetics and low BMI non-diabetic control [Table 1]. It was indicated that diabetic subjects had significantly $(p<0.007)$ lower serum selenium concentration as compared to the non-diabetic control. However, the difference in serum selenium between low and normal BMI diabetes was found to be insignificant $(<0.7)$. When the serum selenium concentrations were categorised into the ranges- $<30 \mu \mathrm{g} / \mathrm{L}, 31-40 \mu \mathrm{g} / \mathrm{L}$ and $>40$ (41-60) $\mu \mathrm{g} / \mathrm{L}$ (respectively marked as $\mathrm{x}, \mathrm{y}$ and $\mathrm{z}$ ) with their corresponding blood glucose levels [Table 2], there was observed a trend of decreasing glucose level with increasing serum selenium value. It was observed that low and normal BMI diabetics having serum selenium value $>40$ (41-60) $\mu \mathrm{g} / \mathrm{L}$ had significantly low blood glucose level. It is to be noted that in controls, serum selenium did not show any influence on the glucose level.Correlation analysis revealed that serum glucose level was inversely correlated with serum selenium level of the diabetic patients [Table 2, Figure 1,2].

Table 1: Serum selenium concentration of diabetics and non-diabetic control subjects

\begin{tabular}{|c|c|c|c|}
\hline Parameter & Low BMI diabetics ${ }^{a}$ & Normal BMI diabetics ${ }^{b}$ & Low BMI non-diabetic ${ }^{c}$ control \\
\hline Selenium $(\mu \mathrm{g} / \mathrm{L})$ & $44 \pm 1646(20-75)$ & $48 \pm 1545(26-120)$ & $59 \pm 3349(23-155)$ \\
\hline
\end{tabular}

Results are expressed as mean and standard (sd) and median (range) as appropriate. ${ }^{\text {abc }} \mathrm{p}=0.007$; ${ }^{\mathrm{ab}} \mathrm{p}=0.700$ 
Annals of International Medical and Dental Research

E-ISSN: 2395-2822 | P-ISSN: 2395-2814

Vol-8, Issue-2 | March-April 2022

DOI: $10.53339 /$ aimdr.2022.8.2.29

Page no- 233-237 | Section- Research Article (Haematology)

Table 2: The correlation between the levels of serum selenium and blood glucose among different study groups

\begin{tabular}{|c|c|c|c|}
\hline Diabetes and control & Selenium range $(\mu \mathrm{g} / \mathrm{L})$ & Glucose level $^{1} \mathrm{mmol}^{-\mathrm{L}}$ & Correlation \\
\hline \multirow[t]{3}{*}{ Low BMI diabetic ${ }^{a}$} & $<30^{x}$ & $11.1 \pm 0.6$ & $\mathrm{r}=-0.33, \mathrm{p}=0.42$ \\
\hline & $31-40 y$ & $10.5 \pm 3.1$ & $\mathrm{r}=-0.97, \mathrm{p}=0.14$ \\
\hline & $>40(41-60)^{z}$ & $9.4 \pm 4.0$ & $\mathrm{r}=-0.53, \mathrm{p}=0.01$ \\
\hline \multirow[t]{3}{*}{ Normal BMI Diabetic ${ }^{b}$} & $<30^{x}$ & $14.21 \pm 9.6$ & $\mathrm{r}=-0.10, \mathrm{p}=0.89$ \\
\hline & $31-40 y$ & $10.17 \pm 6.0$ & $\mathrm{r}=-0.30, \mathrm{p}=0.24$ \\
\hline & $>40(41-60)^{z}$ & $9.20 \pm 4.0$ & $\mathrm{r}=-0.31, \mathrm{p}=0.03$ \\
\hline \multirow[t]{3}{*}{ Low BMI non-diabetic ${ }^{c}$} & $<30^{x}$ & $3.62 \pm 0.4$ & $\mathrm{r}=-0.06, \mathrm{p}=0.85$ \\
\hline & $31-40 y$ & $3.67 \pm 0.5$ & $\mathrm{r}=-0.20, \mathrm{p}=0.60$ \\
\hline & $>40(41-60)^{z}$ & $3.62 \pm 0.5$ & $\mathrm{r}=-0.04, \mathrm{p}=0.82$ \\
\hline
\end{tabular}

Results are expressed as mean and standard deviation (SD).

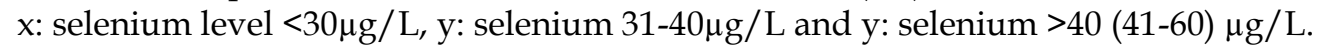

ANOVA (Bonferroni) was performed to find out the significance among the glucose value.

1a $\mathrm{F}(2,27)=0.14,{ }^{1 x y} \mathrm{p}=0.81,{ }^{1 y z} \mathrm{p}=1.0,{ }^{1 x z} \mathrm{p}=0.39,{ }^{1 b} \mathrm{~F}(2,67)=1.18,{ }^{1 x y} \mathrm{p}=0.11,{ }^{1 y z} \mathrm{p}=1.0,{ }^{1 x z} \mathrm{p}=0.04,{ }^{1 c} \mathrm{~F}(2,47)=0.30,{ }^{1 x y} \mathrm{p}=1.0,{ }^{1 y z}$ $\mathrm{p}=1.0,1 \times \mathrm{x} \mathrm{p}=1.0$

Correlation was performed using Pearson correlation and Spearman's where appropriate. $\mathrm{P}<0.05$ was taken minimum level of significance.

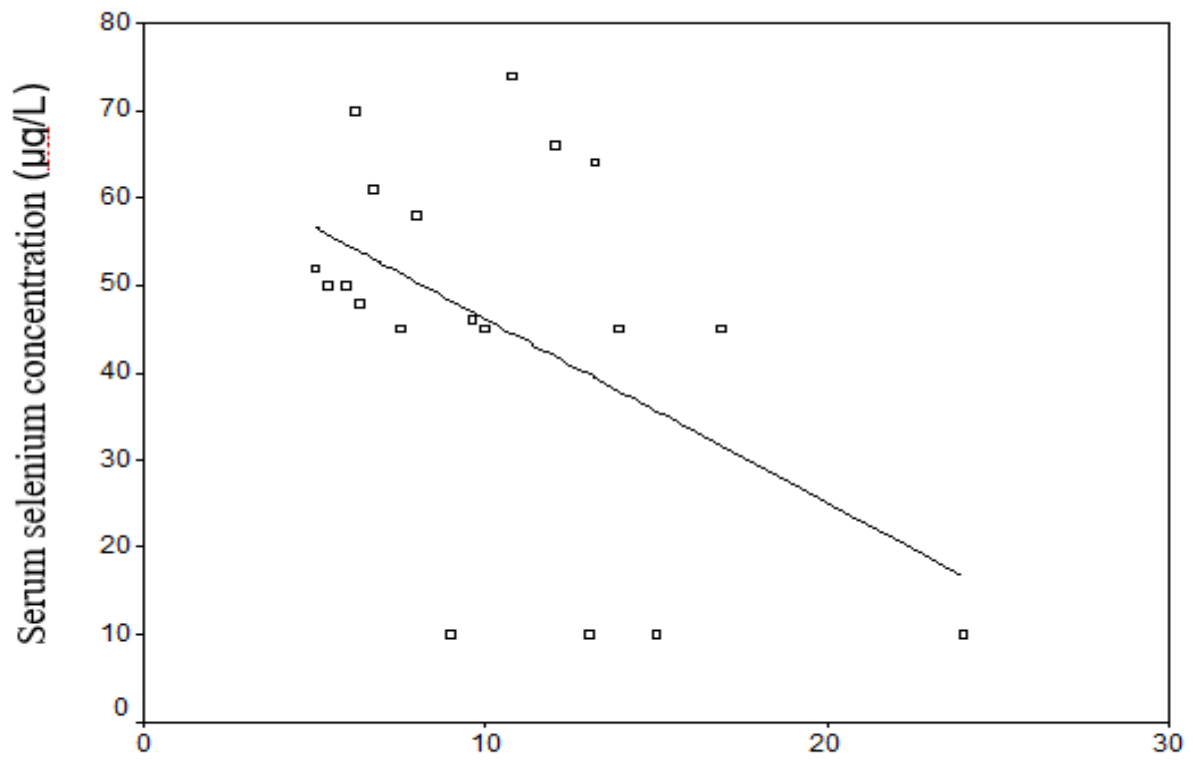

Blood Glucose level (mmol/L)

Figure 1: Correlation between serum selenium concentration andblood glucose levels in low BMI diabetic subjects 


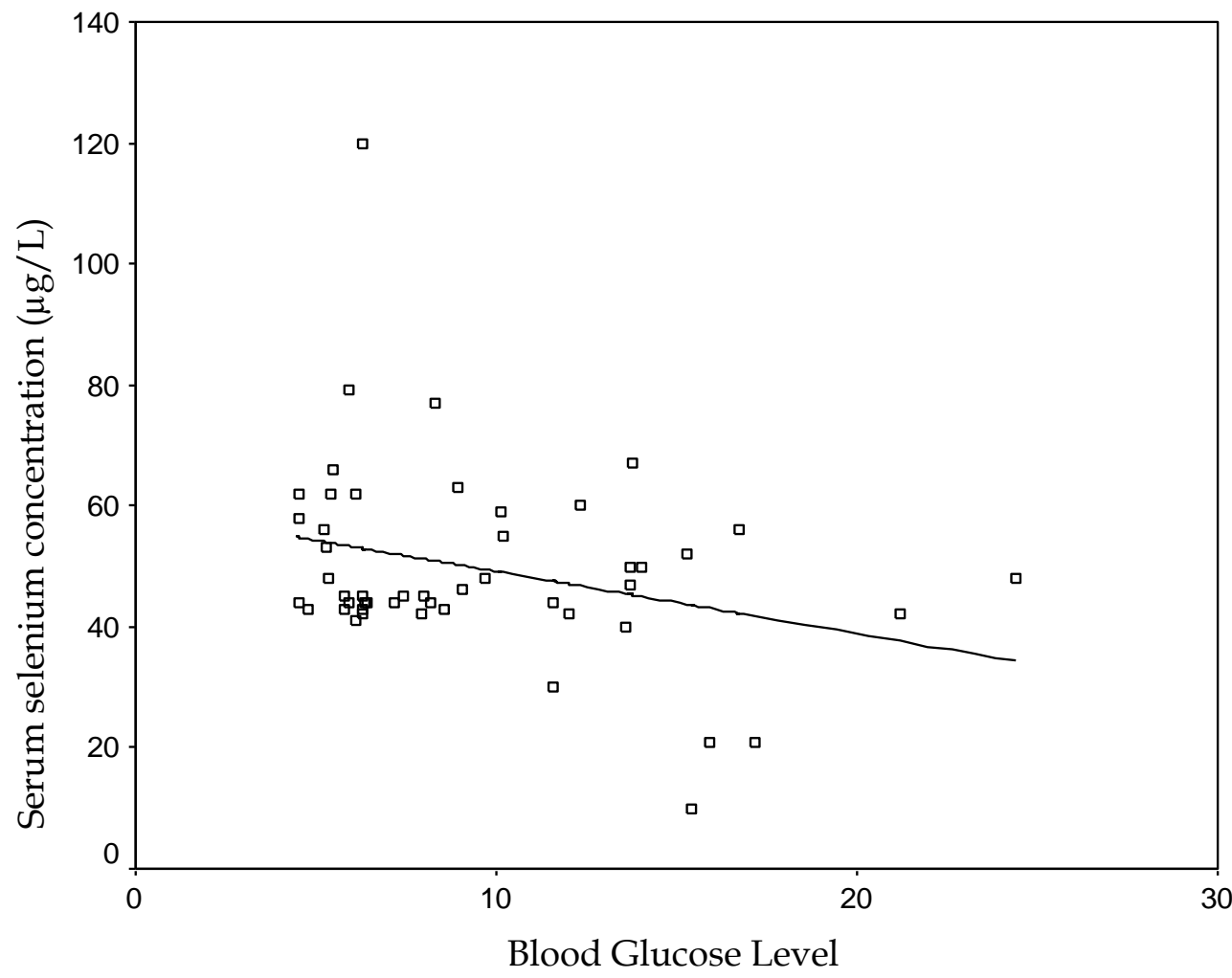

Figure 2: Correlation between serum selenium concentration and blood glucose level of normal BMI diabetic subjects.

\section{DISCUSSION}

In the present study, lower serum selenium concentration was observed in low BMI diabetic patient as compared to normal BMI diabetic patient and non-diabetic controls. This was in line with some previous findings. $\frac{16,17]}{\mathrm{It}}$ has been documented that the oxidative stress has an inverse correlation with nutritional status, [18] therefore, the lower BMI diabetes might have higher oxidative stress and lower serum selenium. The inverse correlation between serum selenium and blood glucose levels as observed in present study has also been reported elsewhere.[2,6] The low serum selenium in low BMI diabetes might be due to an increased oxidative stress, $[\underline{[0,9,10]}$ which in turn might have caused an increased loss of selenium. [1,2] This increased loss of selenium decreases antioxidant defense, and thus, results in hyperglycemia or diabetes.

\section{CONCLUSIONS}

Selenium has a trend of inverse correlation with blood glucose in type 2 diabetes. At a concentration of $>40 \quad(41-60) \mu \mathrm{g} / \mathrm{L}$, serum selenium has significantly inverse correlation with blood glucose level in type 2 diabetes. 
Annals of International Medical and Dental Research E-ISSN: 2395-2822 | P-ISSN: 2395-2814

Vol-8, Issue-2 | March-April 2022

DOI: 10.53339/aimdr.2022.8.2.29

Page no- 233-237 | Section- Research Article (Haematology)

\section{REFERENCES}

1. Kaur B, Henry J. Micronutrient status in type 2 diabetes: a review. Adv Food Nutr Res. 2014;71:55100. doi: 10.1016/B978-0-12-800270-4.00002-X.

2. Rayman MP, Stranges S. Epidemiology of selenium and type 2 diabetes: can we make sense of it? Free Radic Biol Med. 2013;65:1557-1564. doi: 10.1016/j.freeradbiomed.2013.04.003.

3. Steinbrenner H, Speckmann B, Pinto A, Sies H. High selenium intake and increased diabetes risk: experimental evidence for interplay between selenium and carbohydrate metabolism. J Clin Biochem Nutr. 2011;48(1):40-5. doi: 10.3164/jcbn.11002FR.

4. Lu CW, Chang HH, Yang KC, Kuo CS, Lee LT, Huang KC. High serum selenium levels are associated with increased risk for diabetes mellitus independent of central obesity and insulin resistance. BMJ Open Diabetes Res Care. 2016;4(1):e000253. doi: 10.1136/bmjdrc-2016-000253.

5. Park K, Rimm EB, Siscovick DS, et al. Toenail selenium and incidence of type 2 diabetes in U.S. men and women. Diabetes Care. 2012;35(7):15441551. doi:10.2337/dc11-2136

6. Bleys J, Navas-Acien A, Guallar E. Serum selenium and diabetes in U.S. adults. Diabetes Care. 2007;30(4):829-34. doi: 10.2337/dc06-1726.

7. Yuan Z, Xu X, Ye H, Jin L, Zhang X, Zhu Y. High levels of plasma selenium are associated with metabolic syndrome and elevated fasting plasma glucose in a Chinese population: A case-control study. J Trace Elem Med Biol. 2015;32:189-94. doi: 10.1016/j.jtemb.2015.07.009.

8. Wang XL, Yang TB, Wei J, Lei GH, Zeng C. Association between serum selenium level and type 2 diabetes mellitus: a non-linear dose-response metaanalysis of observational studies. Nutr J. 2016;15(1):48. doi: 10.1186/s12937-016-0169-6.

9. Satyanarayana S, Sekhar JR, Kumar KE, Shannika LB, Rajanna B, Rajanna S. Influence of selenium (antioxidant) on gliclazide induced hypoglycaemia/anti hyperglycaemia in normal/alloxan-induced diabetic rats. Mol Cell Biochem. 2006;283(1-2):123-7. doi: 10.1007/s11010006-2387-2.
10. Wright E Jr, Scism-Bacon JL, Glass LC. Oxidative stress in type 2 diabetes: the role of fasting and postprandial glycaemia. Int $\mathrm{J}$ Clin Pract. 2006;60(3):308-14. doi: 10.1111/j.1368 5031.2006.00825.x.

11. Maritim AC, Sanders RA, Watkins JB 3rd. Diabetes, oxidative stress, and antioxidants: a review. J Biochem Mol Toxicol. 2003;17(1):24-38. doi: 10.1002/jbt.10058.

12. Tangvarasittichai S. Oxidative stress, insulin resistance, dyslipidemia and type 2 diabetes mellitus. World J Diabetes. 2015;6(3):456-80. doi: 10.4239/wjd.v6.i3.456.

13. Tiwari BK, Pandey KB, Abidi AB, Rizvi SI. Markers of Oxidative Stress during Diabetes Mellitus. J Biomark. 2013;2013:378790. doi: $10.1155 / 2013 / 378790$.

14. Wang XD, Vatamaniuk MZ, Wang SK, Roneker CA, Simmons RA, Lei XG. Molecular mechanisms for hyperinsulinaemia induced by overproduction of selenium-dependent glutathione peroxidase- 1 in mice. Diabetologia. 2008;51(8):1515-24. doi: 10.1007/s00125-008-1055-3.

15. Mooradian AD, Morley JE. Micronutrient status in diabetes mellitus. Am J Clin Nutr. 1987;45(5):877-95. doi: 10.1093/ajcn/45.5.877.

16. Kornhauser C, Garcia-Ramirez JR, Wrobel K, PérezLuque EL, Garay-Sevilla ME, Wrobel K. Serum selenium and glutathione peroxidase concentrations in type 2 diabetes mellitus patients. Prim Care Diabetes. 2008;2(2):81-5. doi: 10.1016/j.pcd.2008.02.003.

17. Navarro-Alarcón M, López-G de la Serrana H, PérezValero V, López-Martínez C. Serum and urine selenium concentrations as indicators of body status in patients with diabetes mellitus. Sci Total Environ. 1999;228(1):79-85. doi: 10.1016/s0048-9697(99)000340.

18. Moreira PL, Villas Boas PJ, Ferreira AL. Association between oxidative stress and nutritional status in the elderly. Rev Assoc Med Bras (1992). 2014;60(1):75-83. doi: 10.1590/1806-9282.60.01.016.

Source of Support: Nil, Conflict of Interest: None declared 